\title{
$\mathrm{NaOH}$ 처리에 의한 Agrobacterium 이용 팽이균사체 형질전환
}

\author{
신동일 · 박희성* \\ 대구가톨릭대학교 생명공학과
}

\section{Agrobacterium-Mediated Transformation of Flammulina velutipes with $\mathrm{NaOH}$ Treatment}

\author{
Dong-Il Shin and Hee-Sung Park* \\ Department of Biotechnology, Catholic University of Daegu, Kyungsan, Kyungbuk, 712-702, Korea
}

(Received 20, September 2011., 2nd Revised 13, November 2011., Accepted 14, November 2011)

\begin{abstract}
Agrobacterium harboring vector pCHBs with hygromycin phosphotransferase $($ hph $)$ and hepatitis B virus surface antigen(HBsAg)gene was transformed into the mycelial culture of Flammulina velutipes. In particular, mild $\mathrm{NaOH}$ solution was treated to the mycelia before Agrobacterium infection step. This was purposed to generate putative surface wounds in the mycelial cell walls. The results showed that hygromycin-resistant(hyg ${ }^{\mathrm{r}}$ ) mycelia could be obtained only from $\mathrm{NaOH}$-treated mycelia but not from intact mycelia. The integration of hyg gene in fungal genome was confirmed by PCR. In addition, a single transgene integration and heterologous protein expression in $F$. velutipes could be verified by Southern blot hybridization and western blot analysis, respectively. This study demonstrated an efficient tool for the Agrobacterium-mediated transformation of $F$. velutipes mycelia.
\end{abstract}

KEYWORDS : Agrobacterium, Flammulina velutipes, Mycelium, NaOH, Transformation

팽이버섯은 기타 식용버섯들과 마찬가지로 다양한 기능 성을 지니는 것으로 잘 알려져 있으며(Wasser and Weis, 1999) 현재 병재배 방식으로 대량생산이 가능하다. 그러나, 팽이버섯에 대한 biofactory 또는 분자 육종 연구는 많지 않은 편으로서 이에 대한 실용적 형질전환 수단의 개발은 가 치가 있을 것이다. 팽이버섯을 포함한 사상균(filamentous fungi)의 형질전환은 주로 electroporation, polyethylene glycol, biolistic bombardment 방법들을 통한 원형질체, 균사체, 포자 내로의 DNA도입에 의존하고 있다. 그러나 이들 방법은 재현 성과 효율성 면에서 여전히 미흡하다(Meyer, 2008). 한편, Agrobacterium 감염을 이용한 식물의 효율적 형질전환을 위하여 다양한 인위적 요소들이 소개된 바 있는데 삼투조 절물질(Uze et al., 1997), 건조(Cheng et al., 2003), 계면활성제 (Cheng et al., 1997), 감압진공(Bechtold and Pelletier, 2000), 항괴사물질(Enriquez-Obregon et al., 1998; Olhoft and Somers 2001), 물리적 상해(Singh and Chawla 1999; Flores Sols et al., 2003; Kim et al., 2007), phenol 화합물(Pan et al., 1993) 등의 처리가 그 예이다. 한편, 화학적 상해법도 소개된 바 있다(Shin and Park, 2008).

본 연구는 팽이버섯 균사체에 대하여 $\mathrm{NaOH}$ 용액을 처리 하여 화학적 상해를 유발시키고 이를 이용한 Agrobacterium 이용 형질전환효율 개선을 목적으로 두고 실시하였다.

$\overline{\text { *Corresponding }}$ author <E-mail : hspark@cu.ac.kr>
팽이(Flammulina velutipes; KACC 50024) 균사체는 농업 유전자원정보센터로부터 분양받았으며 potato dextrose $\operatorname{agar}(\mathrm{PDA})$ 에서 배양 $\left(25^{\circ} \mathrm{C}\right.$, 암조건 $)$ 하였다. 형질전환용 vector 는 pCAMBIA1300을 XbaI, Klenow fill-in 및 HindIII 순 서로 처리한 후 이를 $\mathrm{pBIHBs(Shin} \mathrm{and} \mathrm{Park,} \mathrm{2008)를} \mathrm{EcoRI,}$ Klenow fill-in, HindIII 순서대로 처리하여 얻은 $2.0 \mathrm{~kb}$ DNA와 접합하여 발현벡터(pCHBs)를 제조하였다(Fig. 1C). 이를
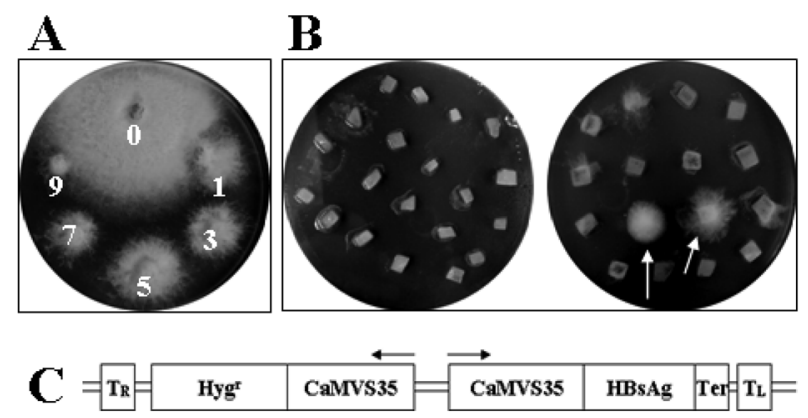

Fig. 1. Transformation of $F$. velutipes mycelia by $\mathrm{NaOH}$-assisted Agrobacterium infection.

A. Mycelial growth for 7 days after the treatment of $0.4 \% \mathrm{NaOH}$ for $0 \sim 9 \mathrm{~min}$.

B. Appearance of hyg $^{\mathrm{r}}$ mycelia (arrows) after Agrobacterium-mediated transformation using intact mycelia (left) or $\mathrm{NaOH}$-treated mycelia (right).

C. Schematic view of T-DNA region of pCHBs. 
A. tumefaciens LBA44404에 도입하여 형질전환에 이용하였다. pCHBs는 CaMVS35 promoter: hygromycin phosphotransferase (hph) 유전자 및 CaMVS35 promoter: hepatitis B virus surface antigen $(\mathrm{HBsAg})$ 유전자를 지니고 있다.

팽이버섯 균사체를 이용한 형질전환을 위하여 $\mathrm{pCHBs}$ 를 보유한 A. tumefaciens를 LB배지(kanamycin $50 \mu \mathrm{g} / \mathrm{ml}$, streptomycin $50 \mu \mathrm{g} / \mathrm{ml}$ 포함)에서 배양 $\left(28^{\circ} \mathrm{C}, 180 \mathrm{rpm}\right)$ 하고 MS 배지(Murashige and Skoog, 1962)로 현탁하였다 $\left(\mathrm{OD}_{600}=1.0\right)$. Agrobacterium 현탁액 $3 \mathrm{ml}$ 을 $\mathrm{PDA}$ plate (88 mm 직경) 상의 팽이 균사체에 첨가하고 실온에서 방 치 $(30 \mathrm{~min})$ 하였다. 현탁액을 충분히 제거 후 동시배양 $\left(22^{\circ} \mathrm{C}\right.$, 2 days)을 실시하였으며 agar포함 균사체 조각 $(5 \mathrm{~mm}$ 정도 크기)으로 제조하여 hygromycin(hyg) 및 cefotaxime 포함 (각각 $50 \mu \mathrm{g} / \mathrm{ml}$ 및 $250 \mu \mathrm{g} / \mathrm{ml}$ ) PDA로 옮겨 hyg $^{\mathrm{r}}$ 균사체를 배양하였다. 한편 $\mathrm{NaOH}$ 균사체처리에 의한 Agrobacterium 형질전환을 위한 전 단계실험으로 $\mathrm{NaOH}$ 농도별 균사체의 생육을 조사하였다. 균사체 disc(ca. $5 \mathrm{~mm}$ 직경)를 준비한 후 $\mathrm{NaOH}$ 용액을 농도 별(0.1 1.0\%) 시간 별(0 9 min) 처리하여 생육 저해 정도를 관찰하였는데 $0.4 \% \mathrm{NaOH}$ 의 경우 $1 \sim 5 \mathrm{~min}$ 처리에서 일정한 생육저해가 나타났으며 이에 비해 $9 \mathrm{~min}$ 처 리의 경우 심하였다(Fig. 1A). 이 결과는 기타 처리 농도 및 기간에 비하여 생육 저해 비교가 상대적으로 용이하였는데 $0.4 \% \mathrm{NaOH} 1 \mathrm{~min}$ 처리를 균사체 생육 유지 및 화학적 상해 유발 조건으로 정하여 형질전환작업에 적용하였다. $\mathrm{PDA}$ 배지 상의 균사체에 대하여 $0.4 \% \mathrm{NaOH}$ 용액을 1 분 처리하여 화학 적 상해를 기대하였으며 이어서 3 회의 멸균수 세척 및 $\mathrm{pH} 5.7$ 의 $\mathrm{MS}$ 배지로 30 분 침지 후 이를 제거하고 같은 종류의 배 지에 현탁되어 있는 Agrobacterium 세포를 첨가하여 형질전 환 작업을 수행하였다. 실험결과로서 $\mathrm{NaOH}$ 를 처리하지않고 Agrobacterium 을 감염시킨 균사체를 2일 간의 동시배양 후 100 개 균사체 조각을 항생제 선발배지에 옮겨 10 일 정도 배양하였던 바 $\mathrm{hyg}^{\mathrm{r}}$ 균사체 출현은 전혀 관찰되지 않았다 (Fig. 1B). 한편, $0.4 \mathrm{M} \mathrm{NaOH}$ 로 처리하고 Agrobacterium을 감염시킨 균사체의 경우 100 개의 균사체 조각들 중 27 개에서 $\mathrm{hyg}^{\mathrm{r}}$ 균사체가 출현하였는데 (Fig. 1B) 이로써 $\mathrm{NaOH}$ 를 이용 한 화학적 상해발생이 Agrobacterium법을 통한 팽이 균사체 형질전환에 매우 효과적임을 시사하였다. 각 $\mathrm{hyg}^{\mathrm{r}}$ 균사체 로부터의 가장자리 일부는 $\operatorname{disc}(5 \mathrm{~mm}$ 크기) 형태로 채취 하여 새로운 항생제 선발 배지에 옮겼으며 최종 3차 선발 과정을 거치도록 하였다. 그 후 hyg 미포함 PDA에서 생육시 켜 형질전환 분석에 이용하였다. Silicon carbide(Singh and Chawla, 1999)나 aluminum oxide(Kim et al., 2007) 등의 미세 입자 또는 초음파(Floros et al., 2003)를 이용 한 식물조직에 대한 물리적 상해 발생 및 이를 통한 Agrobacterium 이용 형질전환율 증대가 보고된 바 있는데 그 절차도 매우 간단하다. 그러나 상해 발생을 위하여 $\mathrm{NaOH}$ 용액 을 사용하였는데 미세한 팽이 균사체 새포벽 표면에서의 일률적 상해발생에서 보다 효율적일 것으로 기
대하였기 때문이었다. 강알칼리인 $\mathrm{NaOH}$ 는 펄프, 섬유, 음 용수, 세제 등의 산업에서 또는 과일이나 채소의 화학적 박피에도 이용되고 있다(Floros et al., 1987).

팽이에 대한 형질전환은 균사체를 이용한 원형질체법 (Maehara et al., 2010) 및 electroporation법(Kuo et al., 2010)이 보고되었으며 한편 Agrobacterium법의 경우 주름조직 이용 (Park et al., 2010)이 보고된 바 있으나 균사체 이용은 없다.

형질전환체의 DNA 검정을 위하여 Genomic DNA 분 리를 실시하고 PCR과 Southern blot hybridization을 실시하 였다. Genomic DNA분리를 위하여 PDA배지 상 균사체 $100 \mathrm{mg}$ 정도를 $2.0 \mathrm{ml}$ tube에 수집하고 여기에 $200 \mathrm{mg}$ glass $\operatorname{bead}(40 \mu \mathrm{m}$ 크기) 및 $500 \mu \mathrm{l}$ extraction buffer( $100 \mathrm{mM}$ Tris-HCl, pH 8.0; 20 mM EDTA; $0.5 \mathrm{M} \mathrm{NaCl}$; 1\% SDS] 를 첨가 후 회전교반 $(250 \mathrm{rpm}, 10 \mathrm{~min})$ 을 실시하였다. 원심분 리 $\left(13,000 \mathrm{rpm}, 10 \mathrm{~min}, 4^{\circ} \mathrm{C}\right)$ 후 얻은 맑은 추출액은 두 번 연속해서 phenol/chloroform/isoamyl alcohol 추출을 실시 하였다. 상징액은 isopropanol과 섞어 $(1: 0.6, \mathrm{v} / \mathrm{v})$ 원심분 리 $\left(13,000 \mathrm{rpm}, 20 \mathrm{~min}, 4^{\circ} \mathrm{C}\right)$ 하였으며 침전물은 $95 \%$ ethanol 세척, $\mathrm{TE}$ buffer 용해 및 $\mathrm{RNase} \mathrm{A}$ 처리 $\left(37^{\circ} \mathrm{C} 30 \mathrm{~min}\right)$ 후 DNA 실험에 이용하였다.

PCR검정은 hyg ${ }^{\mathrm{r}}$ 유전자인 hygromycin phosphostransferase (hph)gene을 표적으로 하여 반응 $\left[95^{\circ} \mathrm{C}, 5 \mathrm{~min}: 33 \times\left(94^{\circ} \mathrm{C}\right.\right.$, $\left.30 \mathrm{sec} ; 68^{\circ} \mathrm{C}, 30 \mathrm{sec} ; 72^{\circ} \mathrm{C}, 1 \mathrm{~min}\right): 72^{\circ} \mathrm{C}, 5 \mathrm{~min}$ ]을 실시하고 forward primer(5'-GTCGAGAAGTTTCTGATCGA-3'), reverse primer (5'-GCTGCATCATCGAAATTGCC-3')의 PCR primer 로 $h p h$ 유전자 중 $830 \mathrm{bp} \mathrm{DNA}$ 증폭을 기대하였다. $\mathrm{PDA}$ 배지에서 상대적으로 생육이 더딘 형질전환 균사체들은 제외 하고 비교적 생육이 활발한 것들로부터 genomic DNA를 추출하여 PCR을 수행하였다. 그 결과, 형질전환체(Fig. 2A)

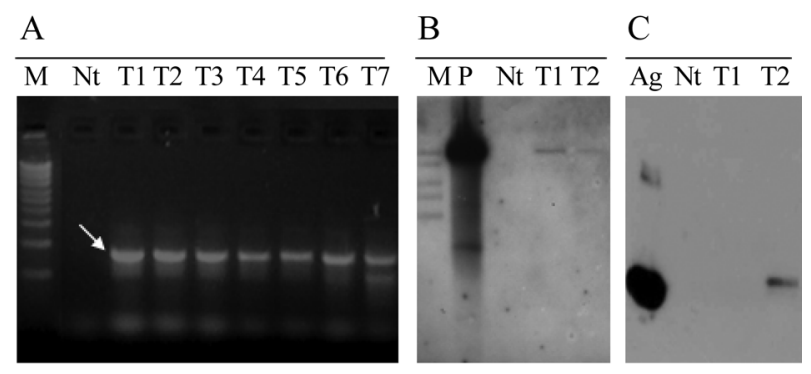

Fig. 2. DNA integration and protein expression in the mycelial transformants of $F$. velutipes.

A. 830 bp DNA products (arrow) amplified by PCR from non-transformed (Nt) and transformed (T1-T7) mycelia. $M$ represents DNA size marker.

B. HindIII-degested DNA fragments from Nt, T1 and T2 genomic DNA hybridized with PCR-amplified $830 \mathrm{bp}$ DNA probe from pCAMBIA1300. $\mathrm{M}$ and $\mathrm{P}$ denote DNA size marker and pCHBs cut with HindIII, respectivly. C. A protein band of ca. $2.4 \mathrm{kD}$ from $\mathrm{T} 2$ shows immunoreactivity with $\mathrm{mAb}$ against hepatitis $\mathrm{B}$ surface antigen (HBsAg). Ag represents yeast-derived recombinant HBsAg. 
모두로부터 $h p h \mathrm{DNA}$ 로 추정되는 $830 \mathrm{bp} \mathrm{DNA}$ 조각이 증폭되었으며 비 형질전환체에서는 나타나지 않았다. 이로써 $\mathrm{hyg}^{\mathrm{r}}$ 팽이 균사체로의 pCHBs DNA 형질전환을 확인할 수 있었다. 일반적으로 Agrobacterium법을 이용한 사상균 형 질전환에서는 single copy의 DNA가 삽입되는 것으로 그 리고 원형질체법의 경우 multi copy가 삽입되는 것으로 알려져 있다(Meyer, 2008).

본 실험에서는 $\mathrm{PCR}$ 에 의하여 $\mathrm{DNA}$ 도입이 확인된 형 질전환체들 중 일부를 대상으로 Southern hybridization을 실시하였다. Southern blot hybridization을 위하여 $5 \mu \mathrm{g} \mathrm{DNA}$ 를 HindIII로 처리 후 $1 \%$ agarose 전기영동을 실시하였고 Nytran membrane전이, probe DNA labelling 그리고 hybridization 결과 확인은 Amersham Gene Images Alkphos Direct Labelling and Detection system(GE Healthcare, $\mathrm{UK}$ )에 의하였다. pCAMBIA1300 plasmid DNA를 대상 으로 위에서 언급한 primer들을 이용한 $\mathrm{PCR}$ 을 실시하였으며 이로써 얻은 $830 \mathrm{bp} \mathrm{DNA} \mathrm{산물을} \mathrm{probe} \mathrm{DNA로} \mathrm{이용하였다.}$ $H i n d I I I$ 로 절단한 genomic DNA와 $h p h$ probe DNA와 hybridization을 수행한 결과 $10 \mathrm{~kb}$ 전후의 단일 DNA band만 이 관찰됨으로써 (Fig. 2B) Agrobacterium법에 의한 single copy 삽입을 재 확인할 수 있었다.

다음은 형질전환체에서의 $\mathrm{HBsAg}$ 단백질 발현여부를 조사 하기 위하여 형질전환체로부터 단백질 추출을 실시하였다. $200 \mathrm{mg}$ 균사체를 $3 \mathrm{ml}$ extraction buffer $(100 \mathrm{mM}$ Tris-HCl, pH 7.0; $5 \mathrm{mM}$ EDTA; $5 \mathrm{mM} \beta$-mercaptoethanol; $1.5 \%$ polyvinyl pyrrolidone; $100 \mu \mathrm{M}$ phenylmethyl sulfonyl fluoride) 및 $300 \mathrm{mg}$ glass bead와 섞어 막자사발에서 충분히 갈아준 후 원심분리 $\left(13,000 \mathrm{rpm}, 20 \mathrm{~min}, 4^{\circ} \mathrm{C}\right)$ 를 실시하였다. 맑은 추출액은 ethanol과 섞어 $(1: 4 \mathrm{v} / \mathrm{v})$ 냉동처리 $\left(-20^{\circ} \mathrm{C}\right.$, $1 \mathrm{hr})$ 후 원심분리 $\left(13,000 \mathrm{rpm}, 30 \mathrm{~min}, 4^{\circ} \mathrm{C}\right)$ 하였으며 침전물은 extraction buffer에 녹였다. 이를 membrane filter $(0.45 \mu \mathrm{m})$ 에 통과시켜 SDS-PAGE 및 western blotting에 이용하였으며 ECL Amersham ECL Protein Biotinylation Module/System (GE Healthcare, UK)에 의하여 수행하였다. 단백질 정량은 Bio-Rad protein assay에 의하였다. T1 및 T2로부터 추출한 total protein에 대하여 Western blotting을 수행한 결과 $\mathrm{T} 2$ 에서 만이 $2.4 \mathrm{kD} \mathrm{HBsAg}$ 발현 확인이 가능하였다(Fig. 2C). T1 에서의 미발현은 팽이 특정 유전자의 삽입변이에 따른 발 현억제로 추정하고 있다. 사상균에서의 외부유전자 발현을 위하여서는 일반적으로 ascomycetes나 basidiomycetes로부 터의 glyceraldehyde 3-phosphate dehydrogenase genes $(\mathrm{gpd}$ ) 의 promoter가 주로 이용되고 있다(Kilaru and Kes, 2005). 일부에서는 CaMV35S promoter 이용이 소개된 바 있는 데(Sharma and Kuhad, 2010) 본 실험에서도 pCHBs 내 CaMV35S promoter와 연결된 $\mathrm{HBsAg}$ 가 팽이버섯내에서 발현됨을 확인 할 수 있었다.

본 연구에서는 일반적인 Agrobacterium법을 적용하여 형질전환이 어려운 팽이균사체에 대하여 $\mathrm{NaOH}$ 용액의 단순
처리에 의한 화학적 상해를 도입함으로써 형질전환 균사체의 제조가 비교적 용이할 수 있음을 제시하였다. 이러한 결과는 또한 기타 물질을 이용한 화학적 상해의 도입 및 형질전환에 의 이용이 충분히 가능함을 제시하고 있다. 한편, 외래유전자 의 단백질 발현이 일부 형질전환체에서 확인됨에 따라 유용 단백질 발현에의한 신품종 개발과 식용 생물공장으로서의 가능성을 기대할 수 있다.

\section{적요}

팽이균사체의 형질전환을 위하여 Agrobacterium 세포를 사용하였다. 특히, Agrobacterium 세포의 감염단계 전에 약한 $\mathrm{NaOH}$ 용액을 처리하였으며 이로써 균사체 세포들의 표면 상해 발생을 기대하였다. 그 결과, hygromycin 저항성 $\left(\mathrm{hyg}^{\mathrm{r}}\right)$ 균사체는 $\mathrm{NaOH}$ 처리를 거친 경우에서만 출현하였다. 형질 전환 균사체의 $\mathrm{hyg}^{\mathrm{r}}$ 유전자 도입은 PCR로 확인되었으며 또한 Southern blot hybridization과 western blotting 분석에 의하여 단일 유전자 copy의 삽입과 외래유전자의 발현을 확인할 수 있었다. 본 연구는 팽이균사체에 대한 효율적 인 Agrobacterium 이용 형질전환수단을 보여주고 있다.

\section{감사의 글}

본 연구는 2011년도 대구가톨릭대학교 교내연구비 지 원에 의한 것임.

\section{참고문헌}

Bechtold, N. and Pelletier, G. 1998. In planta Agrobacteriummediated gene transfer of adult Arabidopsis thaliana plants by vacuum infiltration. Meth. Mol. Biol. 82:259-266.

Cheng, M., Fry, J. E., Pang, S., Zhou, I., Hironaka, C., Duncan, D. R. I., Conner, T. W. L. and Wang, Y. 1997. Genetic transformation of wheat mediated by Agrobacterium tumefaciens. Plant Physiol. 115:971-980.

Cheng, M., Hu, T., Layton, J. L., Liu, C. N. and Fry, J. E. 2003. Desiccation of plant tissues post-Agrobacterium infection enhances T-DNA delivery and increases stable transformation efficiency in wheat. In Vitro Cell. Dev. Biol. Plant 39:595-604l.

Enriquez-Obregon, G. A., Vazquez-Padron, R. I., Prieto-Samsonov, D. L. de la Riva, G A. and Selman-Housein, G. 1998. Herbicideresistant sugarcane (Saccharum officinarum L.) plants by Agrobacterium-mediated transformation. Planta 205:20-27.

Flores Sols, J. L., Mlejnek, P., Studen, K. and Prochzka, S. 2003. Application of sonication-assisted Agrobacterium-mediated transformation in Chenopodium rubrum L. Plant Soil Environ. 49:255-260.

Floros, J. D., Wetzstein, H. Y. and Chinnan, M. S. 1987. Chemical $(\mathrm{NaOH})$ peeling as viewed by scanning electron microscopy: pimiento peppers as a case study. J. Food Sci. 52:1312-1316.

Kim, S., Shin, D.-I. and Park, H.-S. 2007. Transient $\beta$-glucuronidase expression in lily (Lilium longiflorum L.) pollen via woundingassisted Agrobacterium-mediated transformation. Biotech. Lett. 
29:965-969.

Kilaru, S. and Kes, U. 2005. Comparison of gpd genes and their protein products in basidiomycetes. Fungal Genet. Newslett. 52:18-23.

Kuo, C. Y., Chou, S. Y., Hseu, R. S. and Huang, C. T. 2010. Heterologous expression of EGFP in enoki mushroom Flammulina velutipes. Bot. Studies. 51:303-309.

Maehara T., Yoshida, M., Ito, Y., Tomita, S., Takabatake, K., Ichinose, H. and Kaneko, S. 2010. Development of a gene transfer system for the mycelia of Flammulina velutipes $\mathrm{Fv}_{\mathrm{V}} 1$ strain. Biosci. Biotechnol. Biochem. 74:1126-1128.

Meyer, V. 2008. Genetic engineering of filamentous fungi - progress, obstacles and future trends. Biotech. Adv. 26:177-185.

Murashige, T. and Skoog, F. 1962. A revised medium for rapid growth and bioassays with tobacco tissue cultures. Physiol. Plant 15:473-497.

Olhoft, P. M. and Somers, D. A. 2001. L-Cysteine increases Agrobacterium-mediated T-DNA delivery into soybean cotyledonary-node cells. Plant Cell Rep. 20:706-711.

Pan, S. Q., Charles, T., Jin, S., Wu, Z. L. and Nester, E. W. 1993. Preformed dimeric state of the sensor protein VirA is involved in plant-Agrobacterium signal transduction. Proc. Natl. Acad.
Sci. USA 90: 9939-9943.

Park, S.-Y., van Peer, A. F., Jang, K.-Y., Shin, P.-G., Park, Y., Yoo, Y.-B., Park, K.-M. and Kong, W.-S. 2010. Agrobacterium-mediated transformation using gill tissue of Flammulina velutipes. Kor. J. Mycol. 38:48-53.

Sharma, K. K. and Kuhad, R. C. 2010. Genetic transformation of lignin degrading fungi facilitated by Agrobacterium tumefaciens. BMC Biotechnol. 10:67-74.

Shin, D.-I. and H.-S. Park. 2008. Expression of recombinant protein from Oenanthe javanic DC. leaf tissues as a biofactory. Kor. J. Biotechnol. Bioeng. 23:554-556.

Singh, N. and Chawla, H. S. 1999. Use of silicon carbide fibers for Agrobacterium-mediated transformation in wheat. Curr. Sci. 76:1483-1485.

Uze, M., Wunn, J., Pounti-Kaelas, J., Potrykus, I. and Sauter, C. 1997. Plasmolysis of precultured immature embryos improves Agrobacterium mediated gene transfer to rice (Oryza sativa L.). Plant Sci. 130:87-95.

Wasser, S. P. and Weis, A. L. 1999. Medicinal properties of substances occurring in higher basidiomycetes mushrooms: Current perspectives (review). Int. J. Med. Mushr. 1:31-62. 